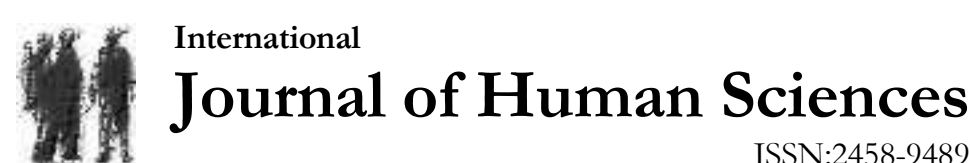

Volume 17 Issue 3 Year: 2020

\section{The role of the age-friendly cities movement in the framework of active aging policies against the socioeconomic risks of demographic aging}

\author{
Aykut Aydin ${ }^{1}$ \\ Muharrem Es ${ }^{2}$
}

\begin{abstract}
Aging, a common problem in almost all countries, both developed and developing, is expressed in terms of a decrease in global birth and death rates or, from a different perspective, an increase in mean life expectancy. Demographic aging, which may be regarded as both a threat and an opportunity, affects a very broad sphere, including basic health, the economy, social security, the saving-consumption balance, living arrangements, urbanization, and the family structure, and therefore brings different disciplines together. Looked at in greater detail, it is a subject that requires reflection and planning since it affects such areas as change in a country's population structure, economic growth, labor markets, labor supply and productivity, development policies, public borrowing, health and social security policies, education policies, and urbanization policies.

The fact that demographic aging is a common problem of both developed and developing countries raises the question of active and healthy aging policies. These policies are thought to play an important role in measures created or potentially created by aging. Discovery of the importance of individual capital accumulation and wide social capital has prepared the dissemination of activehealthy aging policies out of the idea that investment in individuals' health, education, and participation opportunities will benefit both the individual and the community. The emergence of the 'Age-Friendly Cities' movement initiated by the World Health Organization is one concrete outcome of these policies.

The first section of this study will discuss the concept of demographic aging and its relationship with active-healthy aging. The economic and social effects of demographic aging will then be discussed. Another section of the study will discuss the concept of age-friendly cities, their relationship with active aging, and their role against the impacts of demographic aging.
\end{abstract}

Keywords: Old age; elderly; aging; demographic aging; active aging; healthy aging; age-friendly cities and communities.

\footnotetext{
${ }_{1}$ Ph.D. Student, Yalova University, Institute of Social Sciences, Phd Programme of Labor Economics and Industrial Relations, aykutaydn@hotmail.com; (iD) Orcid ID: 0000-0003-2834-1416

2 Prof. Dr., Yalova University, Faculty of Economic and Administrative Sciences, Department of Political Science and Public Administration, muharrem es@hotmail.com; (D) Orcid ID: 0000-0002-7620-7038
} 
Aydin, A., \& Es, M. (2020). The role of the age-friendly cities movement in the framework of active aging policies against the socioeconomic risks of demographic aging. Journal of Human Sciences, 17(3), 847-863. doi:10.14687/jhs.v17i3.6040

\section{Introduction}

The global decrease in both birth and death rates is raising life expectancy on the one hand, while creating a population pyramid that is not being supported by new births on the other. An increasing proportion of elderly individuals within the total population is an indication of demographic aging.

A change in countries' population structures is not limited to a demographic change, but also involves numerous economic and social risks, the majority of which impact on our daily lives, as will be discussed in detail in due course. This paper will refer to probable threats to spheres from health to the economy and social life under various main headings. Many countries have predicted probable risks and taken preparatory action. Developed countries are particular examples of this. However, some developing countries think they have more time available on the subject of demographic aging. Nonetheless, if the current trend in birth and death rates persists, as it may be expected to do, then all countries, both developed and developing, will face these probable risks. The effectiveness of the preparations made will become apparent in the long-term.

The concepts of active and healthy aging emphasize the importance of investment in individual and social capital during the aging process against the potential risks of demographic aging. These need-based concepts have been quickly converted into policies.

As a result of the natural processes discussed above in this study, with its deductive approach, the 'Age-Friendly Cities and Communities' initiative was started by the World Health Organization (WHO), and has since spread significantly. The aim of this initiative is to make cities and communities more age-friendly, to encourage cities and communities to learn about one another by enabling them to remain in contact through a network, and thus to ensure that cities and communities take active aging policies into account during policy-making and implementation based on the idea that an agefriendly community is in fact a community for all ages. The initiative first involved cities, but subsequently began expanding with the inclusion of smaller subunits.

\section{The Conceptual Background}

The concepts of demographic aging, active aging, and the age-friendly city will be considered under this heading.

\section{Demographic aging}

Demographic aging is defined as a proportional growth in the elderly population within the total population of a community. Improved health technologies can help explain the decrease in death rates or increase in average life expectancy, while various sociodemographic factors (such as more women entering the workforce and changing family structures) can help explain decreasing birth rates. As a result of demographic aging, the age structure of a community expands in favor of the elderly.

\section{Active aging}

The WHO defines active aging as the optimization of health, participation, and security opportunities aimed at increasing quality of life as people age (WHO, 2002: 12). This concept rejects the idea that people become more passive as they age, and is based on the proposition that individuals should not be excluded from society so long as they can remain active and healthy, and rather that they should be able to maintain social roles on the basis of their experience.

Active aging relies on various effects or determinants pertinent to individuals, families, and societies. In addition to material circumstances, these also involve social factors impacting on individual behaviors and emotions. In a supportive and facilitatory climate, the elderly can become resources for families, economies, and communities (CSA, 2011:1).

Active aging policies involve a series of broad, active measures involving awareness of real and potential risks resulting from demographic aging and commencing from the early period - a 
Aydin, A., \& Es, M. (2020). The role of the age-friendly cities movement in the framework of active aging policies against the socioeconomic risks of demographic aging. Journal of Human Sciences, 17(3), 847-863. doi:10.14687/jhs.v17i3.6040

preparatory process, in other words. Another aim of these policies is also to create all the physical and social settings for individuals to be able to live active and social lives, and to raise the concept of active aging at the national-local levels.

\section{Age-Friendly Cities}

According to the $\mathrm{WHO}$, an age-friendly city is one that encourages active aging by optimizing opportunities for health, participation, and security in order to enhance people's quality of life as they age (WHO, 2007: 1). Another definition describes an age-friendly city as one that facilitates the active aging process (WHO Center for Health Development, 2013: 5). In practical terms, an age-friendly city is one in which elderly people with different requirements and capacities can access and incorporate structures and services (WHO, 2007: 1).

In an age-friendly city, the local population can decide its own priorities as it ages. This may include encouraging physical design and better access and mobility, encouraging social participation, and improving intergenerational support and relationships. The first rule in establishing an agefriendly city or community is the adoption of an integrated approach to considering the best way to promote elderly people's relationships with their physical and social environments (AGE UK, 2019: $5)$.

Age-friendly characteristics are generally thought of as representing the characteristics of a prosperous environment (physical infrastructure, in other words) or the social environment (in other words, social infrastructure). Physical characteristics typically involve housing, transport and land use, while social characteristics generally include employment and volunteer opportunities, social activities, and numerous community programs and support services (Scharlach, 2016: 311).

\section{Demographic Aging and Socioeconomic Risks}

Sections of society evaluate the economic effects of demographic aging as positive or negative. For example, global aging will increase public debts in order to meet needs caused by rising numbers of retired people. This is a negative phenomenon. However, those sections with a positive view of aging cite the instance of the greatest possible expansion of the service sector in order to meet the needs of the growing elderly population (ENIL, 2012).

In addition to a change in the age structure of the population, demographic transformation also involves economic and social impacts (TUIK, 2012,1). This part of the present study discusses the economic and social risks of demographic aging.

\section{Risks Involving Economic Growth}

Economists, demographers, and politicians have long asked 'How does population affect economic growth and development?' Answers have been sought from a range of perspectives. Different conclusions can be seen in theoretical and empirical studies of the relationship between population and economic growth. According to some of these studies, population increase is a hindrance to economic growth and development, while others suggest that, under different conditions, population growth can spur economic growth (Günsoy and Tekeli, 2015, 36-37 citing Bloom et al., 2002: 3-11).

An aging population can affect the economy from several angles. Most important is its impact through the change it creates in the labor markets. From another perspective, there is the change it produces in the balance between production-consumption and saving, and the consequences thereof.

At the global and national levels, an aging population leads to numerous economic, social, and demographic problems. The most important of the problems caused by an aging population in terms of labor markets is the change in workforce supply. Since an aging population leads to a change in the age components, the population not participating in the workforce and economic activities rises. In other words, as the number of people aged 65 or over rises, the working age population (1564) decreases. Population does not solely alter workforce supply, but also affects workforce 
Aydin, A., \& Es, M. (2020). The role of the age-friendly cities movement in the framework of active aging policies against the socioeconomic risks of demographic aging. Journal of Human Sciences, 17(3), 847-863. doi: $10.14687 /$ ihs.v17i3.6040

productivity, employment, saving, production, and consumption (Günsoy and Tekeli, 2015, 40, citing Bloom et al. 2011, 12-23). A significant relationship exists between consumption and saving and age. A decrease in income among elderly people leaving the labor market (the retired) leads to the greater part of income (pension, interest, rental income etc. not derived from production) being used for consumption, with much less being diverted to savings.

According to King and Jackson, an aging population affects the supply side of the economy by slowing the growth of the workforce in two ways. First, a low fertility rate will reduce the density of young people in the workforce. Second, an older population, and one that will increase still further in the short term, means a weaker workforce. The rate of workforce participation may therefore decline. With a slowing in the growth of one of the basic production inputs, the rate of economic growth will decrease still further, and income will also decline in line with the slowing in the total economic growth rate (King and Jackson, 2000, 9).

However, according to Bloom et al. (2010), an increase in the pension age and migration will in fact be sufficient to help overcome the decrease in the workforce. This will mean that countries are able to maintain economic growth despite the problem of an aging population. For example, Elgin and Tumen (2010) reported that we are facing a fall in individual capital, but maintained that the economy will move from traditional production (using young workers) to human capital-based production (using elderly workers). According to the arguments in this paragraph, an aging population will not impact on production or growth dynamics. Moreover, Elgin and Tumen (2012) state that modern economies rely more on machinery than labor. Therefore, in their opinion, a decrease in the labor force will have no impact on productivity. According to those authors, machines will increasingly replace labor. A decrease in the young worker group will therefore create no effect on economic growth (Nagarajan et al., 2013, 7).

\section{Risks Involving Labor Supply}

A change in the structure of the population affects labor supply and growth in two ways in the short and long terms. In the short term, there is a significant increase in the proportion of the population of working age in the 15-64 age range to the total population due to a fall in birth rates and increased life expectancy. An increase in the working age population and in its labor force participation rate will increase the labor supply, and per capita production will rise when the labor markets are able to employ the growing workforce. Second, production in the labor market will also rise with increasing levels of female participation in the workforce as the working age population increases. This is because women wishing to participate in the workforce require a higher level of education, and a large proportion desire small families (Günsoy and Tekeli, 2015, 56 citing Bloom et al., 2001, 21,).

An aging population will also have adverse long-term effects on labor supply and economic growth. Due to the decrease in birth and death rates, the proportion of people of working age between 15 and 64 in the total population will decrease, and that of the elderly population will increase (assuming that labor supply and productivity are not supported by a range of policies). Again in the long term, and increase in elderly dependence rates will begin to place an economic burden of the working population. If the aging of the population becomes continuous, then longer term employment in the elderly population may be possible if improvements in life expectancy are supported by various policies (such as active aging policies, lifelong learning policies, late retirement, improvement of health services, and increased employment opportunities) (Bloom et al., 2010, 64).

\section{Risks Involving Labor Productivity}

Different studies have reported negative, neutral and positive relationships between age and productivity. It is therefore difficult to generalize how productivity levels will be affected as people age. Several studies investigating the relationship between work performance and age have reported no noteworthy age-based difference in work performances between old and young workers. 
Aydın, A., \& Es, M. (2020). The role of the age-friendly cities movement in the framework of active aging policies against the socioeconomic risks of demographic aging. Journal of Human Sciences, 17(3), 847-863. doi: $10.14687 /$ ihs.v17i3.6040

However, the opinion is also held that productivity levels will decrease as the workforce ages. The first of the two main points on which those who espouse that view rely is the expectation that increased health problems with aging will lower efficiency. Objections to this prediction suggest that a change in the nature of employment occurring with technological changes, and particularly increasingly less reliance on occupations based on physical strength, will reduce the importance of age-related health problems in work performance. A second point of which the exponents of the idea that aging has a negative impact on productivity rely is that the elderly have difficulty in adapting to innovation. Even if it does not reduce individual performance and skills, aging may still delay individual adaptation to changing aspects of work. And this is a sufficient factor for a decrease in individual productivity (Gündoğan, 2001, 103-104, citing OECD, 1998, 12-136). However, there is also the view that an aging population and a decreased younger workforce will represent an opportunity to increase the nature and quality of elderly 'manpower' (Maresova et al. 2015, 535, citing the European Association of Teachers, 2007).

It is certainly not easy to establish a relationship between age and productivity. Productivity is generally a group phenomenon that is difficult to measure at the individual level. Indeed, even when efforts are made to measure it in group form, since a group of workers will generally consist of individuals of different ages, it is still not easy to determine the exact relationship between age and productivity. However, various results can be elicited, despite the limitations of empirical analysis. According to Ours, the potential adverse effects of aging on productivity should be neither over- nor underestimated. In addition, there is no need for excessive concern regarding age-related drops in productivity or age-related wage-productivity. This is due to increased business-specific knowledge and experience. In addition, the position of older workers in the labor market will remain as a political problem. When older workers are unemployed they lose their business-specific individual capital, and the chances elderly unemployed people finding new employment are low (Ours, 2010).

Increased productivity is essentially linked to technological development, 'physical capital' (equipment), and individual capital (training and education levels), and in a broader sense, to investment. Focusing on economic issues does not offer a clear explanation of how population aging will affect these two variables. In the context of technological progress, there are those who think that an aging population will be less susceptible to adaptation to technological advances. Others suggest that an aging population and declining young population will represent an opportunity to increase the amount and quality of 'individual capital' (Maresova et al. 2015, 535, citing the European Association of Teachers, 2007).

\section{Risks Involving Saving and Consumption}

Individuals' consumption and saving behaviors vary by age groups. A change in the population structure will also impact on these behaviors. Since the direction of demographic change is toward an increase in the elderly population across the world, consumption and saving patterns will adapt to the behavioral characteristics of older individuals. Consumer spending among young people is generally directed toward educational and sociocultural objectives, while the majority of older people spend on health instead. In fact, although both young people (especially those in their early working years) and the elderly both engage in significant consumer spending, for the elderly this relies on savings made during their working lives, and they are thus able to balance income and spending (Günsoy and Tekeli: 2015, 63, citing Herrmann, 2012, 32). Elderly people beyond working age and young people engage in greater consumer spending. Low incomes in the non-labor force and retirement payments for those entitled are obstacles to elderly people's ability to save. 
Aydin, A., \& Es, M. (2020). The role of the age-friendly cities movement in the framework of active aging policies against the socioeconomic risks of demographic aging. Journal of Human Sciences, 17(3), 847-863. doi:10.14687/jhs.v17i3.6040

\section{Risks Involving Public Spending and the Sustainability Thereof}

An aging population will very likely affect the government's taxation revenues and increase government spending, particularly on health services, the pension system, and other assistance aimed at the elderly (Tosun, 2003; Nagarajan et al., 2013, 6, citing Elmeskov, 2004). According to Eiras and Niepelt (2012) and Lisenkova et al. (2012), population aging will have an adverse on economic growth by diverting affect the resources the government can allocate to education and infrastructure to social security payments instead (Nagarajan et al., 2013, 6-7). The persistence of existing trends is already sounding warning bells for public finances. Population aging will place significant upward pressure on public spending in the areas of social security for the elderly, and particularly health services (King and Jackson, 2000, 4). Government spending has to rise in line with the aging population. The constant increasing trend in life expectancies is creating direct cost pressures by extending the period during which the elderly age group will consume public goods and services.

\section{Risks Involving Labor Markets}

Falls to be experienced in labor supply are one of the most important economic issues (IMF, 2014). Since the population and its age components are one of the main factors determining labor supply, they have a profound impact on employment and labor markets (Gündoğan, 2001, 99). The elderly population is one of the disadvantaged groups remaining excluded from economic activity or with limited labor force participation for various reasons (physical, psychosocial etc.) associated with reaching a certain age. Population aging results in various direct and indirect outcomes involving labor supply, labor productivity, labor force structure, labor force participation rates, employment, and unemployment (Uyanık, 2017, 86).

\section{Risks Involving Employment}

The fact of aging, which has grown in importance in recent years, and the economic and social burdens to which it is predicted to lead, requires thought and the production of policies. Because employment is not only a tool of economic security, but also entails social benefits. It enables people to survive, shape their lives, and guarantee their futures, and is an indispensable component of modern societies. The employment of elderly adults capable of working in aging countries will bestow micro benefits on individuals and macro benefits on the economy (Aydin, 2017, 1634).

An aging population will inevitably lead to decreased employment in the long term. From another perspective, the structure of employment increasingly expanding in favor of the elderly will require a series of precautionary measures to be taken. These include policies such as late retirement to avoid a decrease in employment, and lifelong education and professional training opportunities to prevent falls in labor productivity and quality or to fill gaps in the workforce in various sectors.

In order to answer the question 'Why should demographic aging be regarded as a threat?' specifically in terms of the labor market, that response must be based on the relationship between production-consumption or, more specifically, from the perspective of social security incomeoutgoings. The most important stream of revenue of social security systems is the contributions deducted from workers' salaries, and to which the employer and the state add in the form of a threeway mechanism in many countries. The state returns a large part of social security revenues back to the community at specific times and under specific conditions. The most important form of expenditure of social security systems is pension payments. It is a known fact that the pension payments made to elderly people who reach retirement age and have earned the right to a pension will increase. In order for social security systems to be sustainable, it is essential that the social security budget revenue-outgoings balance not be impaired. 
Aydin, A., \& Es, M. (2020). The role of the age-friendly cities movement in the framework of active aging policies against the socioeconomic risks of demographic aging. Journal of Human Sciences, 17(3), 847-863. doi:10.14687/jhs.v17i3.6040

\section{Risks Involving Unemployment}

Unemployment has different impacts on young and older workers. The most pronounced difference is that when elderly workers are unemployed, it takes them much longer to find a job than younger workers. Indeed, very few older workers looking for a job are actually able to find it. OECD data for a few developed countries show that more than half of unemployed people aged 55 were unemployed for more than a year. This means long-term unemployment. The majority of these individuals meet the definition of 'disadvantaged workers.' In some countries, elderly workers may feel excluded from the labor market due to changes in occupational structures and a more educated workforce favoring younger workers being needed (Kinsella and Phillips, 2005, 32).

Since young people have greater mobility in almost all areas, they also have greater job change rates than older workers. Changing jobs becomes more difficult with age. Since elderly workers are generally in more senior positions, they tend to enjoy greater salary and job satisfaction than younger workers. On the other hand, as described above, elderly workers have low employment mobility. The most significant reasons for this are difficulty in finding new employment possibilities when they become unemployed (particularly those with problems in terms of education-professional training, or seniority-work experience), difficulties in adapting to changing technological conditions, and changing occupational requirements as the nature of occupations changes. For all these reasons, older workers are reluctant to face the possibility of unemployment and therefore to against the existing status quo.

It is a fact that young people are easily able to adapt to changing economic conditions through continuing education and occupational changes. However, this is less easy for the elderly. Education is becoming a key factor for solving the problem of aging. As the statistics on the subject show, a better educated workforce means higher activity and saving rates capable of creating more resources for lower unemployment and advanced social security systems (Serban, 2012, 361-363).

\section{Risks Involving the Balance between Work and Retirement}

New views and beliefs about working at more advanced ages are emerging as a result of demographic change. The traditional path that regards elderly workers as people needing to leave the workforce early is giving way to the view in which adding workers are regarded as a resource (Bohlinger and Loo, 2010, 28). Institutional differences in welfare systems affect participation in the labor force and age models and distributions for retirement. In countries that permit early retirement and/or behave in a generous manner, early retired workers are widespread. There is a wide unused labor capacity in countries such as Austria, Italy and France, in which 'healthy' individuals are not included in the workforce. Which factors affect people's decisions to work or retire? There is more than one answer to that question. Long-term data indicate that health and family circumstances play an important role in decisions regarding work and retirement (Brugiavini, $2005,240)$. Considering the variety of factors that prevent elderly workers from carrying on working, retirement reform alone will not be sufficient to increase employment opportunities for the elderly. Financial incentives attached to retirement systems and other forms of welfare assistance also play an important role in the decision to work or retire. The question of whether there is a correct policy on this subject can be answered from various different perspectives. Since the workforce in aging countries will become an increasingly rare resource, policies are being developed to make the greatest possible use of the older workers in the labor force. One such policy is the avoidance of a high indirect tax burden if older people prefer to continue working. Almost all countries are introducing reforms in order to overcome employment obstacles and increase flexibility in the decision to work or retire. The common features of these reforms include lowering retirement replacement rates, raising official and early retirement ages, and actuarial adjustments or changes to pension for early and late retirement. In more general terms, it is difficult to achieve an appropriate balance between encouraging late retirement and increasing flexibility in the decision to work or retire. For example, partial retirement has begun being applied in several 
Aydin, A., \& Es, M. (2020). The role of the age-friendly cities movement in the framework of active aging policies against the socioeconomic risks of demographic aging. Journal of Human Sciences, 17(3), 847-863. doi:10.14687/jhs.v17i3.6040

countries (being subsequently abandoned in some), but if reductions in working time are seriously supported, there is a risk of decreases, rather than increases, in the effective labor supply of older workers (OECD, 2006, 11).

\section{Risks Involving Labor Migration}

Developed countries have embarked on initiating various policies against increasing dependency rates. These include liberalization of migration laws, encouraging high birth rates, raising taxes, and reducing pensions. Migration policies have become particularly important in maintaining the proportion of people aged 65 and over to those aged 15-64 (U.N., 2000 cited by Johnson, 2004, 54). Incoming migration policies are a passive solution for developed countries, although the solution is simpler compared to developing countries. This is because, comparing the consequences of an aging population, developing countries are thought to have a lower ability to develop policies (particularly from the financial perspective) than developed countries.

\section{Risks Involving Health Policies}

People's dependency increases as they age, and this represents a clear threat to health systems (ENIL, 2012). In the light of this threat, the change in demographic structure makes reforms in health and social security systems essential. A need for reform in the health system in terms of care and protection services has arisen for reasons such as decreasing fertility rates, decreased death rates, increased life expectancy, and increased elderly dependency rates. Meanwhile, reform in the social security system has become necessary in terms of retirement age, length of retirement, pensions, working conditions for the elderly, and duration of work (Günsoy and Tekeli, 2015, 76).

The population aging seen in many countries means that have to place particular focus on health and social service-assistance projects. Examination of health spending shows that the lowest spending goes to children, and that health spending increases with age and increases many times after the age of 50 . Health spending on the elderly population is four to five times greater than spending on the younger population. Individual health spending on the population aged 65 and over is particularly high. The population aged 85 years and over consumes twice the health services of the 75-84 age group and three times that of the 65-74 age group (Alemeyehu and Warner, 2004: 627).

One significant part of health spending goes on drug and treatment expenses, and the costs are high. Developing countries generally import the products needed by their health sectors, and the high costs of these will mean that an aging population places a heavy burden on budgets.

\section{Risks Involving Social Security}

Social security institutions are perhaps the bodies that are most affected by aging. An increasing proportion of elderly people in the population will further increase dependency rates (Altan and Şişman, 2003: 4-5). This will in turn lead to an increased burden on the insured, and to countries' social security institutions experiencing difficulties in meeting payments (Aydın and Sayllan, 2014, 77). A change in the demographic structure resulting in increasingly fewer workers paying premiums, but in a population receiving greater payments, thus making it difficult to respond to social security needs through premium-based systems. To the extent that it reduces incomes by reducing the number of premium-paying workers, an elderly population is a parameter that increases the number of people receiving pension payments and the duration of such payments (Alper et al., 2012, 40).

\section{Risks Involving Family Structures and Relations}

Family structures, and relations with relatives and neighbors were already in transition before aging became a problem. The distinguishing features of new types of families are small, single-parent families due to separations, nuclear or single-parent families with grandfathers or grandmothers living with them, and families consisting of spouses and children with no official ties of matrimony. A 
Aydin, A., \& Es, M. (2020). The role of the age-friendly cities movement in the framework of active aging policies against the socioeconomic risks of demographic aging. Journal of Human Sciences, 17(3), 847-863. doi: $10.14687 /$ ihs.v17i3.6040

change in the family structure will also change head of family-wife relationships in the traditional family, house-work-woman relationships, relationships between parents and children and the traditional roles involved, as well as the social security functions of the family. Changing family structures require new social security measures, particularly in terms of the care of the elderly and children, and children's education (Alper et al., 2012, 30-31), and also affects the need for official and unofficial support systems for the well-being of the elderly population in particular (Velkoff, 2001, 2).

\section{Risks Involving Living Arrangements}

Living arrangements are affected by such factors as marital status, financial status, family size and structure, relationships with relatives, the availability of social services and support, the housing stock, and the physical characteristics of local communities. Comparisons of countries' in terms of living arrangements have resulted in a number of observations. The first of these is that as women age in developed countries they live more by themselves compared to men, while elderly men more typically live with a spouse in a family environment. Second, the proportion of elderly people living alone in developed countries is rising. Third, elderly men and women in less developed countries generally live with their adult children. Fourth, the use of non-family institutions in the care of dependent elderly people varies considerably across the world, but it is nevertheless relatively low everywhere. Potential risks involving living arrangements as the population continues to age in both developed and less developed countries are related to the support and care of elderly individuals. The living arrangements of the elderly population will impact on demand for official and unofficial support systems (Velkoff, 2001: 1-2).

\section{Risks Involving Urbanization}

It will be useful to examine aging and urbanization from two perspectives. The problems experienced by elderly people living in smaller rural settlements such as hamlets and villages and who later migrate to the big cities will be different to those of elderly people who were born in big cities. Elderly people coming to work in the city from villages and small towns and growing old in cities, or older people forced to grow old in big cities because their children have migrated primarily experience problems of adaptation. Leaving their own social circles and the homes where they spent at least a significant part of their lives and endeavoring to adapt to a totally different environment to that which they had hitherto experiences is a very great problem. On the other hand, rapid urbanization brings with it a decrease in, and sometimes total loss of, family support. The place of the elderly inside the family has been significantly changed by such factors as traditional extended families being replaced by nuclear ones, the emergence of single-parent families in developed countries, the loss of women's carer roles within the family due to female participation in the labor force and employment, and younger generations being better educated and enjoying greater status due to having much better opportunities than their parents in almost all areas (Köroğlu and Köroğlu, 2015, 818).

The nature of the accommodation and environment in cities with increasing elderly populations due to demographic aging is also important. The homes and environment in which they live can be sources of either well-being or unhappiness for the elderly. The homes in which they live and the environment in which they spend time provide opportunities for older people to age in a physically, mentally, and emotionally healthy manner. In other words, urban measures capable of increasing the well-being of the elderly, such as comfortable accommodation, districts free of crime, safe streets and roads with adequate lighting, age-friendly community planning and district layout, age-friendly mass transportation, parks and walkways for physical activities, and appropriately priced and accessible facilities for health, shopping and social activities, are all important in combating the problems faced by an aging population (Sivam, Karuppannan, 2008, 2,3). 
Aydın, A., \& Es, M. (2020). The role of the age-friendly cities movement in the framework of active aging policies against the socioeconomic risks of demographic aging. Journal of Human Sciences, 17(3), 847-863. doi:10.14687/jhs.v17i3.6040

\section{The Age-Friendly City Movement in the Framework of Active Aging Policies}

\section{The Background to the Age-Friendly Cities Movement}

Population aging and urbanization are two global trends involving the main forces shaping the $21^{\text {st }}$ century world. It is expected that more than $80 \%$ of elderly people in the world will be living in developed countries, and that one in four will be a city-dweller (CSA, 2011: 1). The tendency of the world population to come together in cities represents a potential problem, particularly for the elderly. Living in a large city may result in problems for the elderly associated with alienation, neighbor support, health, social services, transport, and entertainment (Woo, 2013: 1).

The idea that best means of overcoming this demographic difficulty is for older citizens to remain as active as possible is attracting increasing popularity. This requires action to encourage the concept of the 'Age-Friendly Environment' in domains such as transportation, the built environment, urban planning, and health and care services. The elimination of existing problems that prevent the elderly being treated as equal to other citizens will allow everyone to age more healthily and to remain independent for longer. This will also help reduce the burden on health and care budgets and allow all generations to cope with demographic aging in a sustainable and just manner (Parent and Wadoux, 2016: 248).

The growth of cities due to migration, and the natural aging of cities, is another domain requiring action. The fundamental reason underlying the WHO Age-Friendly Cities and Communities movement is to help cities prepare for this state of affairs.

\section{The Road to the Age-Friendly Cities Movement}

The roots of the age-friendly cities movement go back to the concept of active aging set out in the UN International Year of Older Persons in 1999. The active aging framework has been included in the policies of several countries (such as the United Kingdom, Australia, New Zealand, the USA. Norway, Japan and Singapore). The WHO has expanded this concept beyond participation in the labor force or physical activity, in order to include the idea that the elderly should have the opportunity to participate in 'social, economic, cultural, spiritual and civil affairs' (Barusch, 2013: 466). Policies and programs aimed at establishing active aging are thought to require a range of interventions, including measures at the level of the social and physical environment. This idea was taken still further when the WHO initiated its Global Age-Friendly Cities project in 2006. Focus groups were established consisting of elderly people, carers, and service providers in 33 cities across the world. A checklist consisting of action points addressed aspects of service provision such as health services and transport, as well as environmental dimensions such as housing, outdoor spaces and buildings, and social aspects such as civil and social participation (Buffel et al., 2016: 278). Changes in the social and physical environment are believed to have the potential to support active aging (Barusch, 2013: 466).

\section{Global Age-Friendly Cities: A Guide}

Discussions at the World Congress of the International Association of Gerontology (2005) in the Brazilian city of Rio de Janeiro provided the first motivation for the creation of a Global AgeFriendly Cities Guideline. The World Health Organization established 158 focus groups involving 1485 participants in 33 cities worldwide. The guideline is based on eight age-friendly themes, for each one of which a discussion of the relevant age-friendly characteristics is provided in the light of a checklist (Ontario Seniors Secretariat, 2013: 93). Creating an age-friendly city requires comprehensive evaluation of the various components of a city's physical and social infrastructure. The WHO employs a standardized method for focus group research and assessing communities' age-friendly status (Plouffe and Kalache, 2010: 735). 
Aydın, A., \& Es, M. (2020). The role of the age-friendly cities movement in the framework of active aging policies against the socioeconomic risks of demographic aging. Journal of Human Sciences, 17(3), 847-863. doi:10.14687/jhs.v17i3.6040

The objective of the WHO was to assist cities and communities on the subject of selfevaluation based on a series of criteria in eight key areas. This was also one of the aims behind the establishment of the Global Age-Friendly Cities: A Guide and the Checklist of Essential Features of Age-Friendly Cities (O'Hehir, 2014: 7). The checklist produced by in the 33 participating using a 'bottom-up approach' provided a set of standard features that can be compared by consulting the elderly residents of a city (Plouffe et al., 2016: 20); it defined the basic features of an age-friendly city from the perspective of the elderly and of service providers and became a reference text for cities in developing and developed countries (Davey, 2017: 11).

The guideline strongly recommends that elderly people be included in all stages of activity, and that cities wishing to become age-friendly should adopt an inter-sector approach. Since that time, the WHO intervention has been applied in different societal contexts in several different locations. The methodology was subjected to adaptation, and the eight original areas were modified by the addition of various elements whose presence had been insufficient, particularly unofficial social networks, social support, security, and security concerns (Plouffe et al., 2016: 32).

The guideline provides a structured guide to how indicators can be selected, defined, and measured; however, it is not a mandatory document. It was designed to be adaptable in order that the indicators can be selected and measured in a local and appropriate manner (Warth, 2016: 43-44).

Table 1: Key Dimensions Contributing to Being an Age-Friendly City

\begin{tabular}{|c|c|}
\hline Key dimensions & Definition \\
\hline $\begin{array}{c}\text { Outdoor spaces } \\
\text { and buildings }\end{array}$ & $\begin{array}{c}\text { Concerns the structured environment and the urban landscape. Contains } \\
\text { such issues as quality of life, access, and security. }\end{array}$ \\
\hline Transportation & $\begin{array}{c}\text { Involving accessible and reasonably priced public transport. Access to } \\
\text { community and health services affects participation in social and civil } \\
\text { activities. }\end{array}$ \\
\hline Housing & $\begin{array}{c}\text { Involves such aspects of housing as design, structure, and economic } \\
\text { preference. Affects security and wellbeing. }\end{array}$ \\
\hline $\begin{array}{c}\text { Social } \\
\text { participation }\end{array}$ & $\begin{array}{c}\text { Involves participation in spare time, social, cultures, and spiritual activities in } \\
\text { the community. Affects remaining healthy and mental health. }\end{array}$ \\
\hline $\begin{array}{c}\text { Respect and } \\
\text { social inclusion }\end{array}$ & $\begin{array}{c}\text { Includes such issues as age-related discrimination and lack of } \\
\text { intergenerational bonds. Affects intergenerational solidarity. }\end{array}$ \\
\hline $\begin{array}{c}\text { Civic } \\
\text { participation } \\
\text { and } \\
\text { employment }\end{array}$ & $\begin{array}{c}\text { Includes the elderly contributing to their communities through paid } \\
\text { employment or voluntary work. Affects remaining active and wellbeing } \\
\text { levels. }\end{array}$ \\
\hline $\begin{array}{c}\text { Communication } \\
\text { and information }\end{array}$ & $\begin{array}{c}\text { Involves the prompt obtaining of accessible, practical information. Affects } \\
\text { being informed and independent, and remaining active. }\end{array}$ \\
\hline $\begin{array}{c}\text { Community and } \\
\text { health services }\end{array}$ & $\begin{array}{c}\text { Necessary to preserve independence and health; involves high quality, } \\
\text { appropriate and accessible care and support services. Affects physical and } \\
\text { mental health, and quality of life. }\end{array}$ \\
\hline
\end{tabular}

Source: Briana Zur and Debbie Laliberte Rudman citing the WHO (2007) "WHO Age Friendly Cities: Enacting Societal Transformation through Enabling Occupation," Journal of Occupational Science, C. 20, No: 4, 2013, p. 370-381.

\section{An Evaluation of the Eight Domains of Age-Friendly Cities and Communities}

Outdoor spaces and buildings have a significant effect on the mobility, quality of life, and 'aging in place' of the older people. The WHO listed such age-friendly features as an attractive and clean environment, green spaces, recreation areas, age-friendly pavements, accessibility, a safe environment, walkways and bicycle paths, and age-friendly buildings (WHO, 2007: 12-16). As the populations of cities increase, it becomes ever more important for older people to able of be integrated into cities, or for cities to be integrated to older people. The social exclusion aspect of cities 
Aydin, A., \& Es, M. (2020). The role of the age-friendly cities movement in the framework of active aging policies against the socioeconomic risks of demographic aging. Journal of Human Sciences, 17(3), 847-863. doi: $10.14687 /$ ihs.v17i3.6040

has led to conditions specific to the physical environment also being considered among the domains of age-friendly cities. These are therefore discussed under the heading of "outdoor spaces and buildings in the guideline. Improvements to the physical environment of a city or community will allow the elderly to live for longer and in connection with their city or community, to remain independent, active and mobile, and even to participate in spare time and voluntary activities by spending more time out of their homes.

Transport is one of the domains that reflects the physical environment in such a way as to create opportunities for people of all ages in a city or community to remain independent and mobile and to age in an active manner. Transport, public and individual, is of great importance in terms of making use of a city's opportunities. Like other population groups, older people also make use of transport opportunities. The basic element that distinguishes them from other population groups are the reasons for their transportation choices. A significant part of their transportation revolves around spare time activities. However, spare time activities are important to active aging, and transport plays a significant role in this. According to the WHO focus group study, the most important point for elderly adults making use of transport opportunities is availability (the degree to which transport services extend through the city, the density of transportation points). Another important element is reasonable pricing. These are the two factors with the greatest impact on the mobility of elderly adults. Older adults have greater physical limitations. Their transportation is therefore one of those subjects requiring particular consideration. It must be remembered that the maximum possible elimination of obstacles to their mobility will bring numerous benefits with it. Age-friendly transportation will bestow significant benefits, such as physical and mental health, socialization and participation, independence, and quality of life. Appropriate and sustainable pricing should also be remembered since a significant proportion of older people are outside the labor market, and transport is of course an expense. Therefore, no matter the breadth of transportation, transport involving the elderly must be affordable.

Another domain making cities and communities age-friendly is that of housing. The issue of housing is one that must be specially considered for older people since these are outside the labor market, since old age pension payments represent the main economic resource of the majority, and since older people who have been unable to become home-owners during their working years will in all likelihood still be renting in old age. Specially designed and affordable housing options must be made available for non-property owners in particular to allow them to continue living without being split away from their immediate surroundings. Residential building initiatives likely to impose a heavier burden on local administrations in smaller settlements outside metropolitan cities require local governments to cooperation with central government, and sometimes the private sector or various housing cooperatives. The provision of social housing is not only important for the elderly, but also for all low income individuals or families. Loan repayments in order to become a homeowner or rent payments on the part of renters represent an important proportion of incomes. Public sector intervention in this area, either alone or in partnership with the private sector, is therefore inevitable in many countries. Finding a solution to cities housing problems is therefore one important step on the road to becoming age-friendly.

One of the consequences of the age-friendly city movement is increased awareness of age discrimination. Based on the idea that any policy planned for older people will actually benefit all ages, it may be concluded that age-friendly policies will also contribute to intergeneration solidarity.

On the other hand, 'respect and social inclusion,' one of the criteria for age-friendly cities, is based on a lack of intergenerational relations. Although the WHO provides clues to the resolution of this deficiency, it has also allowed flexibility in terms of the administrations to producer and maintain age-friendly initiatives. The application of numerous projects and measures aimed at reducing age-based discrimination or encouraging solidarity between the generations is already desirable within the framework of the constant cycle of improvement of cities and communities that is the WHO's essential aim. 
Aydin, A., \& Es, M. (2020). The role of the age-friendly cities movement in the framework of active aging policies against the socioeconomic risks of demographic aging. Journal of Human Sciences, 17(3), 847-863. doi:10.14687/jhs.v17i3.6040

One of the environments that an age-friendly city wishes to create in a city is one that prevents social exclusion by supporting socially inclusive policies. On this subject, the WHO makes perhaps the greatest reference to social participation policies within its published criteria. Social participation is generally interpreted as a broad concept, essentially based on the individuals and groups that make up the community. These individuals or groups must be included in all socially-based activities aimed at increasing interaction with others. Although this is a natural process, there is no lack of policies aimed at encouraging social participation. The fact that the WHO and age-friendly cities stress social inclusion policies derives from findings such as that older people taking part in social inclusion policies will have a better quality of life, their happiness levels will rise, and their feelings of isolation will decrease. Voluntary participation activities are particularly important to social inclusion. There will be many benefits to older people taking part in voluntary settings where they can express their thoughts or engage in various activities. Most importantly, their perceptions of themselves as passive individuals will change. Learning taking place during activities is another benefit of social participation. Older people coming together with members of other groups of any age will contribute to solidarity through an exchange of information and experience among the generations, and to natural medium- and long-term inclusion.

Although the age-friendly city domain of civic participation and employment has been defined as a separate entity, it can also be regarded as a subdomain of social participation. Various participation activities not intended for social purposes, such as every individual living in a city or community voting, serving on various bodies, or at least assuming some responsibility, are an expression of civic participation. The employment domain is actually sufficiently important to be considered by itself. What makes it important is that it endures economic security on the one hand, while representing an important part of active aging, the subject of this paper.

Communication and information is another dimension of a social nature in age-friendly cities and communities. Special interest may need to be shown concerning informing older people among disadvantaged groups about various activities or services. As technology has progressed, the mass media have begun being replaced by new communications technologies, and the low rate of older people employing these technologies (difficulties in accepting or adopting innovations) has been one of the dimensions addressed by the age-friendly movement. Age-friendly cities and communities must enable the elderly to access the requisite information through accurate and appropriate channels, within the required amount of time, and to access all forms of information stations.

Community support and health services are some of the important services that can be procured age-friendly cities and communities. Although a large proportion of health services in particular are provided by central administrations, local administrations also have a growing responsibility in the provision of these services. The role of local administrations regarding social services is more visible. The wide variety of social services have resulted in central administrations in many country sharing out these responsibilities. Indeed, local administrations possess significant advantages in the provision of the services needed by local residents, such as proximity, speed, easy accessibility, and familiarity. There will of course also be non-official aspects to the health and social services to be provided. The private sector and volunteer organizations have brought with significant benefits including increased options, accelerated searches for quality (especially the private sector), scope expansion (in meeting the needs of more people), and availability.

\section{The Global Network for Age-Friendly Cities and Communities}

The WHO initiated the Global Network for Age-Friendly Cities and Communities with the aim of encouraging the application of its policy proposals in 2010 (Buffel et al., 2016: 278). The Global Network was brought into being in order to apply the WHO's age-friendly cities and communities policy, to identify areas for improvement, to being together local administrations seeking to adopt their policies in their relations with the elderly, and to apply policies and measures aimed at making cities and communities more age-friendly (Warth, 2016: 37). 
Aydın, A., \& Es, M. (2020). The role of the age-friendly cities movement in the framework of active aging policies against the socioeconomic risks of demographic aging. Journal of Human Sciences, 17(3), 847-863. doi:10.14687/jhs.v17i3.6040

The WHO's age-friendly cities and communities approach, based on United Nations (UN) principles for the elderly, the Active Aging Policy Framework, and the Age-Friendly Cities and Communities Guideline, uses participant age-friendly evaluations to establish policies at the local level. Local administrations assess, apply, monitor and plan the advances made within a 'continual improvement cycle.' The network binds together a growing number of cities and communities that adopt this approach to assess the age-friendly status of cities and communities adopting it and to shape their measures (Warth, 2016: 38).

Any community capable of showing that it is actively engaged in becoming more age-friendly can apply for membership of the global network (Davey, 2017: 11). One of the requirements for membership is to have the ability to act on priorities determined throughout the age-friendly city process. The size of the city or community is irrelevant. In order to include smaller communities, and particularly rural areas, the name of the network was changed from 'age-friendly cities' to 'age-friendly cities and communities' (Warth, 2016: 42).

\section{Becoming an Age-Friendly City}

Other than the WHO framework and research protocol, there is no universally accepted approach toward the development of an age-friendly city. Focus group research is just the beginning of the road to age-friendliness. Cities joining the WHO Global Network for Age-Friendly Cities and Communities have to promise to continuously evaluate their age-friendly status in four stages over five years (O'Hehir, 2014: 8-16). The planning stage must involve inclusion of the elderly, analyze the progress made to age-friendliness, and develop a plan of action and identify milestones. The application stage must apply the plan of action and observe the milestones, while the progression stage must measure progress, determine successes and any remaining gaps. Finally, the progress report stage involves sustaining the progress made (WHO, 2009).

\section{Figure 1. The WHO Global Network for Age-Friendly Cities}

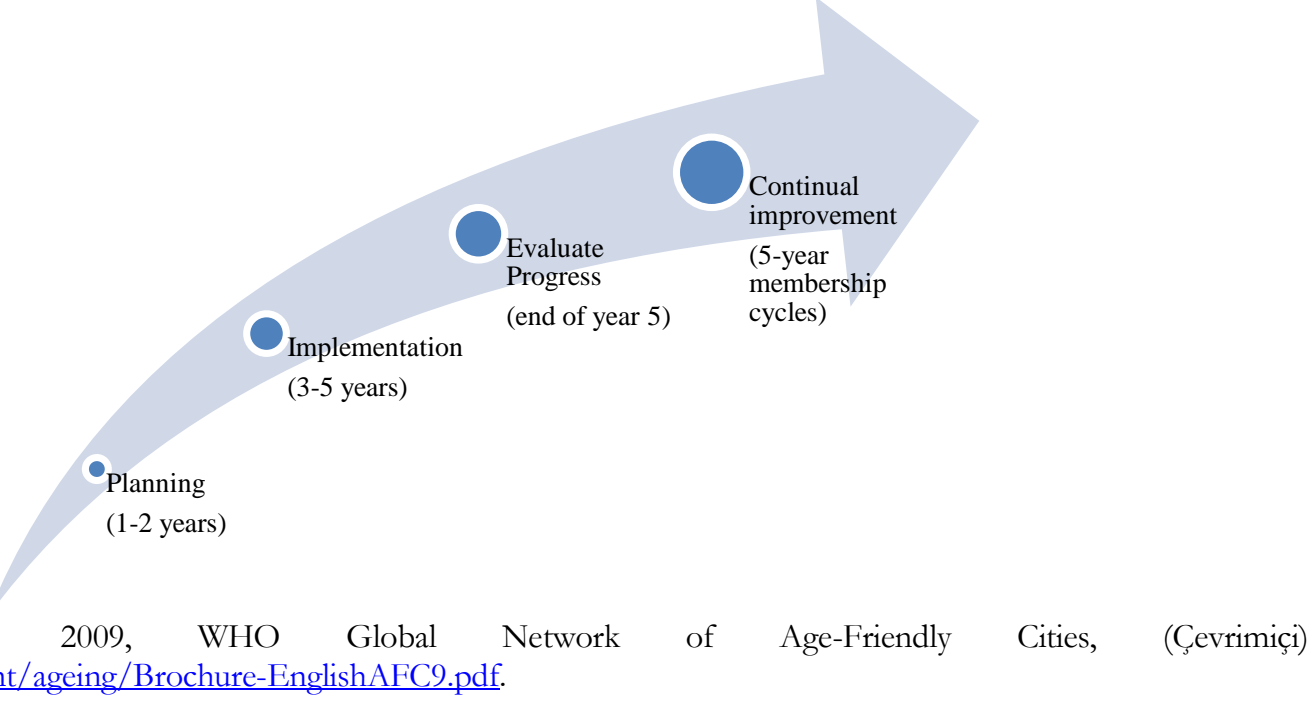

https://www.who.int/ageing/Brochure-EnglishAFC9.pdf.

Cities agreeing to implement the program can become part of the global network and share information (Kendig et al., 2014: 1391). Instructions to cities wishing to join the global network have emphasized that older people must closely participate in all stages of age-friendliness evaluation, planning, and implementation. Those applying must include the eight WHO domains in their assessments. In 2015, the WHO published its "Measuring the Age-Friendliness of Cities: A Guide to Using Core Indicators" report. This guideline provides a framework and a set of indicators guiding the selection of local measures aimed at observing and evaluating cities 'progress toward age-friendly status. The guide also includes references and additional sources, such as local initiatives. Rather than 
Aydın, A., \& Es, M. (2020). The role of the age-friendly cities movement in the framework of active aging policies against the socioeconomic risks of demographic aging. Journal of Human Sciences, 17(3), 847-863. doi: $10.14687 /$ ihs.v17i3.6040

representing a set of prescriptive instructions, the aim is that the indicators should be adopted in the most meaningful, appropriate and requisite manner (Davey, 2017: 12-47).

\section{Conclusion}

The arguments in favor of combating potential and real risks created by demographic aging are being expressed ever more loudly. Policies entering the agenda in developed countries have now also become important for developing countries, due to ideas such as the inevitability of aging, that the effects can only be mitigated through timely intervention through the requisite policies, and that aging can actually be turned into a positive opportunity.

The concepts of active and healthy aging are the main policies for combating demographic aging. These are based on the idea that people no longer subscribe to the belief that they will lose control over their lives as they age and will play reduced roles in their own lives, but that if supported by various policies, and if opportunities to remain active are created, people can continue to shape their own lives and continue to contribute to society.

The Age-Friendly Cities movement also heads the list of increasingly essential measures against the health and socioeconomic risks caused by aging. The aim of this movement initiated by the WHO is to prepare the foundations to allow local, national, or regional administrations to adopt measures aimed at the elderly population in cities, which represent a very significant proportion of the world population. Determination of the eight areas in which it was predicted that city administrations would apply their policies was performed by means of a bottom-to-top mechanism through focus groups also including older citizens, and these were then published by the WHO. Information concerning how the main indicators were to be used in measuring cities' progress toward WHO age-friendly status, one particular problem, was subsequently published. Of course a number of question marks still remain. The most important of these question marks involves the argument that numerous specific characteristics, such as the population size of each city, its socioeconomic structure and resources will affect that city's age-friendly policies. Another question that comes to mind is whether the eight designated domains and key indicators will fit or need to be adapted to the unique characteristics of the cities. Although WHO's attitude towards this matter is to be flexible against urban administrations, it is also a fact that it creates quite relativity in evaluating the agefriendliness of the cities in developed and developing countries.

\section{References}

Age UK. (2019). Age Friendly Places: Making our community a great place to grow older. https://www.ageuk.org.uk/our-impact/politics-and-government/age-friendly-places, 02.09.2019.

Alemayehu, B., \& Warner, K. E. (2004). The lifetime distribution of health care costs. Health services research, 39(3), 627-642.

Alpana, S., \& Karuppannan, S. (2008). Factors influencing old age persons' residental satisfaction: a case study of South Australia. https://tasa.org.au/wp-content/uploads/2011/01/sivan.pdf. 25.11.2017.

Alper, Y., Çağacan, D., Sayan, S. (2012). 2050’ye doğru nüfusbilim ve yönetim: sosyal güvenlik (emeklilik) sistemine bakış. Tusiad.

Altan, O. Z., \& Şişman, Y. (2003). Yaşlilara yönelik sosyal politikalar. Kamu-İs, 7(2), 4-5.

Aydın, A. (2017).Yaşlı işgücünün çalışma hayatındaki sorunları: Kırklareli ili örneği. Journal of Human Sciences, 14(2), 1632-1646.

Aydın, A., \& Sayılan, A. (2014). Aktif yașlanma ile yașam boyu ögrenme arasindaki ilişkiye teorik bir bakış. Uluslararası Sosyal ve Ekonomik Bilimler Dergisi, 4(2), 76-81.

Barusch, A.S. (2013). Age-friendly cities: a social work perspective. Journal of Gerontological Social Work, 56(6),465-472. 
Aydın, A., \& Es, M. (2020). The role of the age-friendly cities movement in the framework of active aging policies against the socioeconomic risks of demographic aging. Journal of Human Sciences, 17(3), 847-863. doi: $10.14687 /$ ihs.v17i3.6040

Bloom, D.E., Canning, D., Finlay, J.E. (2010). Population aging and economic growth in Asia. The economic consequences of demographic change in East Asia. Nber-ease, 19, 61-89.

Bohlinger, S., \& Jasper, V. L. (2010). Lifelong learning for ageing workers to sustain employability and develop personality. Cedefop, 28-57.

Brugiavini, A. (2005). Work and retirement. (ed). Axel börsch-supan etc., health, ageing and retirement in Europe: first results from the survey of health, ageing and retirement in Europe, pp. 235-272.

Buffel, T., Mcgarry, P., Phillipson, C., de Donder, I., Dury, S., de Witte, N., Smetcoren, A.S., \& Verté, D. (2016) Developing age-friendly cities: case studies from Brussels and Manchester and implications for policy and practice. (ed.) Sanchez-Gonzalez, D., \& Rodriguez-Rodriguez, V. Environmental gerontology in europe and latin america: policies and perspectives on environment and aging, Springer, pp. 277-296.

CSA. (2011). Age-friendly cities: an opportunity for friendly aging. http://www.csa.org.lb/cms/assets/archives/2011/5\%20agefriendly $\% 20$ cities $\% 20 a n \% 20$ o pportunity $\% 20$ for $\% 20$ friendly $\% 20$ aging $\% 20$ english.pdf, 11.09.2019.

Davey, J.A. (2017). Age-friendly cities and communities: world experience and pointers for New Zealand. http:/ /www.superseniors.msd.govt.nz/documents/age-friendlycommunities/afcc-report-9-full-report-single.pdf, 02.09.2019.

ENIL. (2012). Intergenerational learning and active ageing. http://www.enilnet.eu/intergenerational_learning_and_active_ageing-european_report.pdf, 10.08.2014.

Gündoğan, N. (2001). İşgücünün yaşlanması ve işgücü piyasalarina etkileri. Ankara Üniversitesi SBF Dergisi, 56(4).

Günsoy, G., Tekeli, S. (2015). Nüfusun yaşlanmasi ve ekonomik büyüme ilişkisi: Türkiye üzerine bir analiz. Amme İdaresi Dergisi, 48(1).

Johnson, R. (2004). Economic policy implications of world demographic change. Federal reserve bank of kansan city economic review. https://www.kansascityfed.org/publicat/econrev/pdf/1q04john.pdf, 12.09.2017.

Kendig, H., Elias, A.M., Matwijiw, P., \& Anstey, K. (2014). Developing age-friendly cities and communities in Australia. Journal of Aging and Health, 26(8), 1390-1414.

King, P.,\& Jackson, H. (2000). Public finance implications of population ageing. Finance Canada working paper.

Kinsella, K., \& Phillips, D.R. (2005). Global aging: the challenge of success. Population bulletin, 60(1).

Koroğlu, C.Z., \& Koroğlu, M.A. (2015). Mekanın dönüşümü ve yaşlilik üzerine: Kentleşme ve yaşl1lık olgusu. Uluslararası Sosyal Araştırmalar Dergisi, 8(41), 812-821.

Maresova, P., Mohelska, H., Kuca, K. (2015). Economic aspects of ageing population. Procedia economics and finance, 534-538.

Nagarajan, R., Teixeira, A.C., Silva, S.T. (2013). The impact of an ageing population on economic growth: an exploratory review of the main mechanisms. Fep working papers.

O’hehir, J. (2014). Age-friendly cities and communities a literature review. Centre for work + life, University of South Australia, July.

OECD. (2006). Live longer, work longer. Executive summary, http://www.oecd.org/employment/emp/36218997.pdf, 06.09.2017.

Ours, J.V. (2010). Age, wage, and productivity. Cepr's policy portal, http://voxeu.org/article/ageingpopulations-and-productivity., 12.09.2017.

Parent, A.S., \& Wadoux, J. (2016). Toward an age friendly European Union”, (ed.) Moulaert, t. And garon, s., age friendly cities and communities in international comparison: political lessons, scientific avenues, and democratic issues. Springer, pp. 247-255, 
Aydın, A., \& Es, M. (2020). The role of the age-friendly cities movement in the framework of active aging policies against the socioeconomic risks of demographic aging. Journal of Human Sciences, 17(3), 847-863. doi:10.14687/jhs.v17i3.6040

Plouffe, 1., Kalache, A. (2010). Towards global age-friendly cities: determining urban features that promote active aging. Journal of urban health: bulletin of the New York academy of medicine, 87(5), 733-739.

Plouffe, 1., Kalache, A., \& Voelcker, İ. (2016). A critical review of the who age-friendly cities methodology and its implementation. (ed.) Moulaert, t. And garon, s., age friendly cities and communities in international comparison: political lessons, scientific avenues, and democratic issues. Springer, pp. 19-36,

Scharlach, A.E. (2016). Age-friendly cities: for whom? By whom? For what purpose? (ed.) Moulaert, T., \& Garon, S. Age friendly cities and communities in international comparison: political lessons, scientific avenues, and democratic issues. Springer, pp. 305-329.

Serban, A.C. (2012). Aging population and effects on labour market. Procedia economics and finance, 356-364.

TUIK (2012). Istatistiklerle yaşlilar. Tuik, http://www.tuik.gov.tr/prehaberbultenleri.do?id=13466. 12.09.2017.

Velkoff, A.V. (2001). Living arrangements and well-being of the older population: future research directions", united nations, department of economic and social affairs, population division.

Warth, 1. (2016). The who global network of age friendly cities and communities: origins, developments and challenges. (ed.) Moulaert, t. And garon, s., age friendly cities and communities in international comparison: political lessons, scientific avenues, and democratic issues. Springer, pp. 37-46.

WHO centre for health development. (2013). 2nd who consultation on developing indicators for age-friendly cities/meeting report. Japan, https://extranet.who.int/kobe_centre/sites/default/files/pdf/afc_mtg2_report_sep2013_ quebec.pdf, 15.08.2018.

WHO. (2002). Active ageing : a policy framework. World health organization.

WHO. (2007). Global age friendly cities: a guide, Geneva.

WHO. (2009). Who global network of age-friendly cities, https://www.who.int/ageing/brochureenglishafc9.pdf, 02.11.2019.

Woo, J. (2013). Aging in Hong Kong: A comparative perspective, Springer.

Zur, B., \& Rudman, D.L. (2013). Who age friendly cities: enacting societal transformation through enabling occupation. Journal of Occupational Science, 20(4), 370-381. 